\title{
Decolonising Durkheimian Conceptions of the International
}

\author{
Colonialism and Internationalism in \\ the Durkheimian School during and \\ after the Colonial Era
}

Grégoire Mallard and Jean Terrier

\begin{abstract}
Over the past 20 years, numerous scholars have called upon social scientists to consider the colonial contexts within which sociology, anthropology and ethnology were institutionalised in Europe and beyond. We explain how historical sociologists and historians of international law, sociology and anthropology can develop a global intellectual history of what we call the 'sciences of the international' by paying attention to the political ideas of the Durkheimian school of sociology. We situate the political ideas of the central figures explored in this special issue-Émile Durkheim, Marcel Mauss, Bronisław Malinowski and Alfred Métraux-in their broader context, analysing their convergence and differences. We also reinterpret the calls made by historians of ideas to 'provincialise Europe' or move to a 'global history', by studying how epistemologies and political imaginaries continued by sociologists and ethnologists after the colonial era related to imperialist ways of thinking.
\end{abstract}

Keywords: Colonialism, Decolonisation, Civilization, Ethnology, Sociology, Émile Durkheim, Marcel Mauss, Bronisław Malinowski, Alfred Métraux

Today, the public interest in the theme of de/colonisation is taking many forms in a wide variety of domains. In the academic world, a new generation of scholars, especially from the social sciences and from international law, has prompted all disciplines to engage in critical self-reflection and asked them to decolonise their curriculum, research methods and epistemologies. Social protests organised by the worldwide Black Lives Matter 
movement after the tragic killings by police officers of Trayvon Martin in 2013 and George Floyd in 2020 have also spurred a worldwide discussion on the legacies of slavery and colonial police brutality in Western societies. Activists and social scientists alike have challenged the ignorance of the general public concerning the legacy of colonialism in Europe, North America and settler colonial societies like Australia. Following the Rhodes Must Fall movement, they have extended the discussion to tackle the issue of how historical ignorance has been perpetuated, enabling colonial signs to remain untouched in the public sphere after decolonisation, most visibly in street names and public statues. This new activism has had an impact on the historiographies of former empires and challenged the cultural codes and social practices that form the core of systemic racism and more subtle forms of post-colonial discrimination.

These movements, of course, are not new, and anthropologists, especially in the Anglophone world, have long reflected upon the co-constitutive formation of ethnology and colonial rule (Cohen 1971; Cohn 1996; Stocking 1987; for newer perspectives, see Go 2008; Steinmetz 2007, 2008, 2013). Over the past 20 years, numerous publications have also called upon scholars to consider all relevant contexts when analysing historical processes of knowledge production: authors have claimed that we should 'provincialise Europe' (Chakrabarty 2000) or move to a 'global history' (Boucheron et al. 2017; Singaravélou 2011; Subrahmanyam 2013) and be more attentive to the contribution of Global South scholars when studying the history of academic disciplines like international law, sociology or anthropology. Undeniably, these calls and methodological shifts have resonated within the social sciences more generally.

Yet overall, save for a few notable exceptions, the sub-disciplines that tell the histories of anthropology, sociology and international law in the twentieth century have remained clearly impervious to most attempts at de-nationalising their object of study and at rejecting 'national' history in the sense of a 'metropolitan' history divorced from the fate of the colonies, overseas territories and the broader world of international relations and international organisations. To take one example, the history of French sociology is often restricted to the study of concepts, practices and schools that emerged in the metropolitan context, and is inscribed in the political metropolitan field rather than contextualised in the broader history of French colonialism and decolonisation (see, for instance, Heilbron 1995).

A lack of interdisciplinary dialogue is also evident: historians of anthropology and sociology continue to ignore recent revisions of the history of international law that have paid attention to global de/colonial processes between North and South (Abi-Saab 1991; Anghie 2005; Becker Lorca 2015; Craven 2007; Pahuja 2011; Rajagopal 2003); just like legal scholars have commonly failed to notice the emerging sociology of colonial knowledge 
and new histories of sociology and anthropology in the interwar period (Mallard 2019; Steinmetz 2007). This lack of dialogue, we hypothesise, is creating obstacles to further theoretical progress as well as to empirical understanding of how the disciplines of sociology and ethnology have evolved in interaction with contemporary attempts to think about the problem of international order.

In this article, we start from the hypothesis that the objects and claimed jurisdictions of international law, anthropology, sociology and political science at the time of their constitution in the interwar period were overlapping. In fact, the division of labour between each discipline was premised, as we will argue, on contested but also shared definitions of the 'international' between certain traditions in each discipline, and such definitions required a delineation of boundaries between national, colonial and international phenomena, which each discipline articulated differently. On this basis, we invite historians of ideas to build upon the history of each of these 'sciences of the international' and to bring them together to develop new perspectives on the history of their disciplines.

To answer this call, social scientists need to answer several questions: What were the imaginaries of the 'international' developed by anthropologists, sociologists and international law scholars in the early days of these disciplines, especially in the interwar era? How were those imaginaries linked to the contexts in which scientists, jurists and administrators developed new legal, political and social technologies to learn about, and administer, populations in various areas of the world, from Europe to the Americas and to colonial territories in Africa and Asia? Were these imaginaries of 'the international' generally associated with the liberal vision of the world order and the defence of human rights, or with exploitative ideologies such as fascism, imperialism or earlier forms of colonialism? How did they survive in the post-war era marked by successful anti-colonial movements up to our day?

In this issue, we initiate a broader reflection that pursues three related goals. First, we want to discuss and assess the state of the art in the most recent historiography of international law, sociology and anthropology. Second, we propose to develop a coherent framework to capture the role of international politics and local processes at play in the creation of an international society of scholars of the 'international', scattered between capitals of international and/or colonial law like Geneva, Paris, The Hague and London. Third, we reflect on what these historical configurations of knowledge about 'the international' can teach us so as to further strengthen interdisciplinary debates between anthropology, sociology and international law today - especially as the disciplines increasingly grapple with challenging ethical, political and methodological issues related to the difficulty of conducting research in transnational settings in which multiple legal and 
normative layers overlap, often marked by post-colonial or neo-colonial organisational mindsets (Mbembe 2001).

To help us accomplish these goals, we have constituted a panel of leading scholars whose research focusses on the history of Francophone and Anglophone anthropology and international law, and especially on the key figures of Émile Durkheim, Marcel Mauss, Bronisław Malinowski and Alfred Métraux. We believe that their collective contribution not only offers convincing general presentations of the evolution of academic fields in the interwar period and beyond, but also that it may be the starting point of even more fruitful intellectual exchanges, bringing to our attention a specific area in global intellectual history where recent research has been particularly productive. Each contributor focusses on a key turning point and a central author in the history of the Durkheimian school: Émile Durkheim and the political debates surrounding the definition of a 'nation' from 1870 to 1914; Marcel Mauss and the controversies in the 1920s over the question of the 'nation' and its relationship with ethnology, comparative law and colonial administration; Bronisław Malinowski and the push for applied ethnology put to the service of the British Empire in the 1920s; and Alfred Métraux and the reinvention of the Durkheimian programme in favour of a global anti-racist movement that sought to take over from the anti-colonial struggles of the 1950s. By commenting on the contributions gathered here on the trajectory of Alfred Métraux and comparing it with that of other Durkheimian and Maussian ethnologists, like Jacques Soustelle, in the postwar era, this article asks whether the colonial mindset was so entrenched in the Durkheimian school that its members failed to think about the future of the nation beyond the colonial era.

Each contribution seeks to locate the author and his work in the context of the debates on the national and the international, as well as in the political context of colonial expansion. As we will show in more detail below, a thread that runs through all the contributions in this issue is the ambiguity of many social science scholars of the first half of the twentieth century vis-à-vis colonisation. On the one hand, these scientists set up the theoretical foundations for a coherent criticism of essentialist racialism and nationalism - some of them, like Marcel Mauss, went as far as developing an ambitious sociology of intersocial and international relations. On the other hand, their critical approach failed to frontally address the parallel questions of colonialism and, for Durkheimians from later generations, decolonisation, which were left to a large extent untouched politically and unexplored intellectually.

One possible conclusion of this historical survey spanning the evolution of key Durkheimian sociological concepts, political ideas and changing epistemologies of the international, associated with either pro-colonial or anti-colonial movements from the 1870s to the 1970s, comprises in our 
view two elements. To begin with, the reflection on the international during the interwar era was deeply framed by the colonial experience, even if only at the level of the concepts and categories used. However, the perception of early social science, especially anthropology, as being nothing more than a discipline to support and facilitate colonisation, a kind of ancilla imperii, is also partly flawed. We take it to be much more productive to envisage the social science disciplines themselves as sites of political and epistemological contestation, in which clear reflections of the key conflicts in the political field at the time can be detected. Nevertheless - and this is our second point, which stands in tension with the first - we believe that especially the Durkheimian tradition would require key conceptual and epistemological transformations before it could address contemporary calls to diversify our knowledge of the international and contribute to social and historical justice through innovative approaches to decolonisation.

\section{The Durkheimian School and the Colonial Turn of the French Republic: A Co-Constitutive Project from 1870 to 1940}

Until now, with a few exceptions (Conklin 2013; L'estoile 2007; L'estoile et al. 2005; Mallard 2018, 2019; Sibeud 2004, 2009), historians of the Durkheimian school of ethnology and sociology have paid little attention to the colonial context that was an intrinsic aspect of Durkheim's reflections on the international order. Amongst other things, the work of the doctoral students that Marcel Mauss gained after the creation of the Institute of Ethnology, which he founded in Paris in 1925, has often been neglected. ${ }^{1}$ This article and the other contributions gathered in this issue test the assumption that there was a constitutive association between, on the one hand, the colonial turn in the French Republican project in which Emile Durkheim was a recognised voice, and, on the other, the rise of sociology as both a new epistemology and a new practice of knowing. Some contributors also address the question of whether Durkheimian authors who lived to implement the Durkheimian programme in the heyday of the French and British Empires in the 1920s, like Marcel Mauss in France or Bronisław Malinowski in Great Britain, challenged the co-constitutive association between ethnology and colonial administration, or if, on the contrary, they strengthened that constitutive link between their emerging discipline and the European colonial project. 


\section{Sociology and the Nation before 1914}

Susan Stedman-Jones in this issue analyses how Émile Durkheim conceived of the concept of 'nation' in relation to the legacy of the first French Revolution of 1789. This article disputes past interpretations of Durkheim's political thought that have placed him in the group of traditionalist or even conservative thinkers who were dismayed by the concomitant rise of individual rights and the Industrial Revolution (Nisbet 1974). It shows that Durkheim conceptualised the 'nation' as a political society of individuals with state-protected rights as opposed to a community with a fixed ethnic identity, and it shows how such Republican conception of the nation - and therefore of the type of international society that could emerge from the concomitant establishment of various nationally autonomous democracies from the ashes of Central European empires - led him to develop important epistemological and methodological reflections about sociology and ethnology. Such reflections include those about how sociologists should avoid the use of reified concepts of ethnicities and other fixed identities when studying 'modern' political groupings such as the 'nation' conceived as a democratic political society of rights-bearing individuals. In StedmanJones's contextual reading, Durkheim stood in a permanent critical dialogue with the nationalist and conservative thinkers of his time. Even his most theoretical and abstract essays can be read in this light: for instance, his famous article on collective and individual representations (Durkheim 1898), with its descriptions of representations as resulting from associations in the mind, highlights the flexibility and changeability of mental life and is thus, Stedman-Jones argues, implicitly directed against essentialism.

Durkheim's political reflections - including during the Great War - were not restricted to the fate of European nations, but also included considerations about Europe's colonial expansion and its relationship with the development of a national consciousness. In the era in which Durkheim was intellectually active, French intellectuals were divided over how to best express France's grandeur after the defeat by the German Army in 1870 . Two main strategies were being debated: the French could recover either by attacking and defeating the German Reich militarily, thereby winning back the region of Alsace-Lorraine, lost during the war and claimed as ethnically German territories by the Reich, or by spreading the rights-based discourse of the French Revolution on a global scale, especially in the colonies that the French Third Republic was conquering in Africa throughout the period.

Authors like Maurice Barrès and Charles Maurras, alongside other nationalists who opposed the establishment of the French Third Republic in general, and its colonial project in particular, ${ }^{2}$ defended the first option. For them, the glorification of France's traditional authoritative bodies - for instance, the army, the Catholic Church, or, in the case of Maurras, the 
monarchy - was to serve the purpose of keeping intact France's will to get quick revenge on the Germans. Their sacralisation of traditional institutions, coupled with their schematic approach to international relations - envisaged as a conflict between allied blocs structured around the friendenemy distinction - explains why they did not associate the creation of a nation with the emergence of discourses and practices designed to protect the rights of diverse individuals defined as citizens within a historically demarcated territory.

This tension between traditional institutions and individual rights, however, did find an especially clear and famous expression in the Dreyfus Affair, during which Durkheim helped establish the League of Human Rights with his nephew Mauss and other Durkheimians (Fournier 1994). Republicans like Jules Ferry and Léon Gambetta opposed the conservative nationalists: both were widely admired Republican figures who were famous for their claim that the values of the Enlightenment should be spread through mandatory, free, secular public education in the French metropolis, and through an extension of the Republic's territorial reach well beyond the historical boundaries of France - not in Europe, of course, but across the globe, especially in Africa, where the French Republic was quickly expanding its territorial supremacy. It is telling that the League of Human Rights was to defend the plight of colonial subjects through its various local committees, including the French Committee for the Protection and Defense of Indigenous Populations (Sibeud 2009).

Durkheim argued that France was special as a society because it may have been the first to institutionalise, to systematise and even to sacralise the typically modern values of individuality, free thought and the participation of citizens in politics within a modern nation. As repeated later by Mauss, Durkheim suggested that France was at the forefront of social modernisation because it substituted ancient collective representations and ancient cults - the cult of the monarch or the cult of the race - with the cult of the individual. The nation thus conceived was different from clans or ethnic groups, as it offered a space where diversity could thrive, as long as all individuals forming its parts were willing to exercise their rights, respect the rights of others and participate in the emotional celebration of humanity. The emotional dimension in the attachment of citizens to their nation was important to Durkheim: it meant that, although the nation's contours and identity could form the object of a rational and critical discourse by individuals, the collective representation of belonging had a force of its own, as it ran deep into the unconscious of its worshippers (Collins 2012). Nevertheless, Durkheim (and Mauss) seems to have believed that the balance between emotional and discursive elements may slowly shift in favour of the latter as societies progressed along the path of modernisation (Terrier 2012). Correspondingly, the identification of universal values and 
principles may in the long run serve as a basis for a new international order, as they could also be shared across different nations: while these elements remained present only in nuce in his work, they were later taken up, as Francesco Callegaro shows in this issue, by Mauss, who envisaged - on explicitly Durkheimian grounds - an international order no longer grounded on hatred, conflict and war, but on reasoned construction, peaceful debate and cross-cultural exchange.

Moreover, Durkheim thought that with the creation of sociology and its foundation on the use of comparative methods it would finally become possible to reveal the real inner workings of societies, which always rest, in the last analysis, on collective representations, even though some of those may not be fully explicit or clear. For instance, in the broader society of nations France's national identity was not only the result of large-scale 'bio-social' phenomena (Brubaker 2015) like the structural history of migration movements, as racialists may argue, it was also deeply cultural, as it involved new subjective understandings of what it meant to be a French citizen. It was not only thinkable, but also probable, that the inhabitants of France, after having added a new form of attachment to their local identities to form a nation, may adopt a further identity beyond the national one, thereby giving birth to une patrie plus vaste - a phrase used by Durkheim, ${ }^{3}$ but also by Republican colonialists like Albert Sarraut, to refer to the projection of the French national identity beyond its European territorial limit. The Durkheimians were convinced of one thing: sociology, as the science of social transformation, could contribute to empower citizens to critically assess the malleability of political societies. It could also help citizens understand that nations are not entities defined once and for all by physiology, climate or territory.

At the same time, this argument was a double-edged sword - and here we reach the definitely ambiguous core of the contribution of the Durkheimians to the reflection on the international and colonial social fact. Indeed, according to the Durkheimian paradigm, the societies of the colonies had different representations, but they were not, contrary to what racialists argued at the time, different in essence from the metropolitan Republic: since the international order (like any social order) was always by nature in flux and ever-changing, the proponents of colonisation could argue that an extension of the Republican project overseas could be pursued without brutalising the social fabric of the subjugated societies. Their opponents could argue, on equally Durkheimian grounds, that the creation ex nihilo of societies and states by way of treaties of annexation or other acts of sovereign power could also violate the rights of individuals amongst the populations living in annexed territories. As the contributions to this issue show, the Durkheimians often balanced their views between these two positions. Most were convinced that colonisation, if anything, 
progressed through a process of cultural reinvention of political identities in which emotions played a major role. At the same time, the question as to whether the brutal annihilation of the humanity of colonial subjects could be fully avoided, or whether it was an unavoidable side-effect of colonial expansion, was treated as an empirical problem, which the comparative sociologist should address with typical axiological neutrality - a position that already assumed the principled acceptability of the colonial project.

Once Durkheim's analysis of the nation is properly understood, and placed in contradistinction to the proto-fascist thinking of right-wing folklorists and intellectuals, we perceive that Durkheim's sociological project was, on the one hand, not devoid of elective affinity with the colonial Republican project and, on the other hand, that it was directed against racialism, in so far as it explicitly rejected any understanding of social cohesion as an effect of physiological traits (Mucchielli 1997). Durkheim's understanding of the social, later taken up (with modifications) by Mauss, envisaged societies as fundamentally capable of exchange in the areas of culture, laws or sense of morality - in other words, they were not condemned to either conflict or war, as in the paradigm of the 'war of races', which Michel Foucault (2003) traced back to French traditional folklorists of the eighteenth century. In contrast to the British colonialists of the Victorian era and German imperialists, who were famous for claiming that amongst the 'races' the white Christian 'race' should vanquish and lead the others (Steinmetz 2007) - which is how they justified colonialism Durkheim developed a complex theory of social change and social cohesion that displayed the characteristic ambiguity we identified above.

His more open and complex understanding of social cohesion made it possible to envisage various forms of intersocial co-operation, all the way up to and including societal mergers - in other words, fusions of social entities. Politically, we observe that such an approach could serve as the basis for multilateralist and democratic concepts of international relations emphasising equality and co-operation, and, at the same time, that it could also be used to justify colonial expansion. To use yet another formulation, we could derive an anti-racist conception of the international order from Durkheim's conception of the nation as an act of progressive self-education - towards human rights and other universal values like self-government - and from his vision of the boundaries between political societies as something fluid and malleable; at the same time, the same social theory could also be used to justify why the French could and should mix with new colonial subjects and form a patrie plus vaste - a bigger and more integrated Republic - clearly different from the concept and practice of the German Reich, which was, in the French vision, an empire established along racial lines. 
Although Durkheim's discourse on the nation entertained a clear affinity with the Republican project, which defended at the time a 'liberal' - and also naïve at best or, at worst, duplicitous - form of colonialism meant to distract European nations from war at home and to spread an emotional attachment to Enlightenment values outside Europe (Koskenniemi 2001), his sociological school did not, in its early days, establish direct ties to the administration of colonial subjects, which remained largely a military operation. Rather, sociology provided a broader epistemological perspective, which, through the development of its comparative methods and its detailed analysis of collective representations, was meant to help intellectuals and citizens deconstruct what some may have previously believed to be eternal truths and essences, like the distinction between national characters essentialised into 'races' (Terrier 2011).

In many ways, Durkheim's sociological perspective on the bases of national and international communities developed alongside other disciplinary attempts to modernise the vision of the international, as proposed by international law scholars who ambitioned to transform the 'classical' paradigm of international relations, which at the time was still founded upon the notion of exclusive sovereignty. As told by Milos Vec and Luigi Nuzzo (2012), or Arnulf Becker Lorca (2015), the discipline of international law in the early twentieth century was a site of deep reformulations of what 'the international' meant. The late-nineteenth-century Victorian and Prussian international law scholars believed that two criteria in particular civilization, characterised by the presence of long-lasting independent institutions of government, and religion, with Christianity inheriting its central place from the symbolic supremacy it had enjoyed for years within the jus publicum Europaeum (Schmitt 2003) ${ }^{4}$ - were key to demarcating acts capable of creating international law from more mundane acts of the foreign projection of force. In contrast, the project started by early-twentiethcentury international law scholars and which took off in the interwar era consisted in reformulating 'modern' international law by placing at its core common rules, as opposed to unilateral acts of sovereignty originating in the law-constitutive Christian 'civilised' nations. These common rules were to be developed in a polycentric manner through the assimilation of peripheral nations, such as the former colonies of the South American continent, into the cradle of civilisation (Becker Lorca 2015), as well as by the proliferation of international organisations expressing solidarity and interdependence between older civilised European nations and the newcomers. In many ways, these reflections, which were sometimes directly inspired by Durkheim's sociological conceptions of the social transposed at the international level (Koskenniemi 2001), remained highly philosophical and speculative until the establishment of the League of Nations, the Reparations Commission and the International Labour Organization (ILO): only after 
the Great War did the Durkheimian proponents of 'modern' international law gain the opportunity to execute their programme from the heights of the various new organisations that were being founded in Geneva at the time (Dhermy-Mairal 2018).

\section{Colonialism and the Interwar Creation and Diffusion of French Ethnology by Marcel Mauss and Bronisław Malinowski}

After the Great War and the defeat of the Prussian, Austro-Hungarian and Ottoman Empires, an epoch-shifting effervescence characterised the diplomatic conferences to establish the resulting international organisations, which were supposed to create an eternal peace between newly constituted nations and which resulted in the 'nation' becoming the solid rock upon which the new 'international' society was to be founded. Empires disappeared even without a process of international legal creation, as in the case of the Czar's empire, which collapsed internally, leaving the Bolsheviks in charge of reassembling a federation of autonomous nations on the outskirts of the European continent. In the Middle East, in provinces formerly under Ottoman rule, the League of Nations was supposed to ensure that the Mandates granted to the British and French victors of the Great War prepared local political societies to become autonomous and eventually self-governing nations.

The polycentric proliferation of rules differently segmenting how the 'intersocial', to use Mauss's concept, was to be lawfully managed - whether by rules of international law, by colonial administration decrees or by joint decisions elaborated by Mandates and High Commissions - turned the dreams of the advocates of 'modern' international law into concrete realities that could be studied positively by a new science of international law. To that extent, the radical transformation of the world of international organisations that followed from the Great War participated in the advent of a positivist approach to international law and a disciplinary specialisation and differentiation between, on the one hand, international law, which was concerned with the study of the legal textual documentation emerging from the myriad organisations (from commissions to courts) that ruled over the 'international', and, on the other hand, ethnology and sociology, which would analyse how social forms of authority evolved as a result of the 'nationalisation' of political forms of sovereignty in Europe and beyond.

After Durkheim's death during the Great War, and the expansion and consolidation of the French and British colonial projects under the purview of the League of Nations, Mauss in France and Malinowski in Great Britain ambitioned to turn sociology and ethnology into more practical and more specialised disciplines directly useful for the administration of colonial subjects in Africa and Asia. Rather than distancing themselves from the 
colonial projects of their nation, they associated, much more deeply than Durkheim ever had, the project of building a new range of disciplines - from ethnology to sociology, anthropology and modern international law - with the goal of acquiring knowledge and skills to rule over French and British colonial subjects. The underlying idea was that the latter should progress towards the goals that the 'international society' had set for them: to manifest the emergence of a national consciousness and to establish the institutions necessary for the development of a sustainable state. The direct relevance of the social sciences for the Wilsonian goals of nation-building expressed in his Eighteen Points and the creation of the League of Nations gave to the new generation of Durkheimians an opportunity to obtain more resources to create their university centres and institutes, often thanks to the benevolent support of the Rockefeller Foundation (Tournès 2011).

Should Mauss's involvement in the French Republic's experience with colonialism be seen as evidence of the association between ethnology and colonial apology - or an attempt to civilise colonialism to ensure its long-lasting presence - which has been condemned by post-colonial scholars like Talal Asad (1973)? Even though neither Mauss nor his students at the Institute of Ethnology, which he created in 1925 to institutionalise Durkheimian ethnology in Paris, contested the colonial principle that France had a civilising mission in the non-European world and that the exchanges between their societies and colonial societies were a priori useful to both the metropolis and the colonies, they did denounce the reality of colonial practices on the ground when the latter destroyed local solidarities and pre-existing modes of thought and when they failed to create the patrie plus vaste that Durkheim had imagined (Mallard 2018).

The notion of 'civilisation' was the main idea behind the European colonial project: it served as a justification for classical international law scholars to support the expansion of British and French tutelage in the Mandates they obtained in the Middle East from the defeated Ottoman and German Empires (Koskenniemi 2001). It also continued to play a legitimating role for the promoters of 'modern' international law, although they understood it differently. For interwar legal scholars, colonialism needed to avoid repeating the pre-war horrors of the Belgian emperor in the Congo (Mallard 2019). To that end, colonialism had to be disciplined by the normative power of good governance, and monitored by the international bureaucrats of the newly created Geneva-based League of Nations. Through the socialising force of Geneva-based institutions, whose work Durkheimian scholars like Célestin Bouglé made known by publishing leaflets and documentation materials through the Centre de documentation sociale (Marcel 2019), the two European democracies (France and Great Britain) that had defeated racist empires were to start a transformative process as they learnt to reject the old religion of sovereignty and to espouse the new cult of international 
co-operation amongst freely organised societies. This new understanding of international law as a limit placed on the exclusiveness of sovereignty also extended to the administration of League of Nations Mandates (placed under the watchful eye of a Geneva-based commission) and colonies. The new form of colonialism - and thus also modern international law - which its priests distinguished from the old and now illegitimate exploitative form of colonialism (Sarraut 1931) and which was associated with the establishment of comptoirs in the slave trade, aspired to the cosmopolitan dream that each co-ruling party (the colonial administration, the metropolitan powers, the local subjects and the international organisations to which each reported) would accept limits on their sovereignty if these limits ensured the preservation or pursuance of a peaceful future - forever elusive, critics would say with good reason - by freely co-operating nations. ${ }^{5}$

As Callegaro writes, and as Jean Terrier and Marcel Fournier (2013) had previously acknowledged, Mauss's interwar writing on the 'nation' expanded some of his prior reflections on 'civilisation', published jointly with Durkheim in 1913, and participated in redefining the meaning of the legal concept of 'civilisation'. The colonial diffusion of French 'civilisation', for Durkheim, and then Mauss, meant something quite different from how colonial apologists of 'Western civilisation' understood it at the time. For Durkheim, the expansion of a civilisation to new territories could not be conceived as a simple change in the institutions of government. In the Durkheimian/Maussian vision, the concept of 'civilisation' means a family of societies - in other words, an ensemble of social entities that are distinct, but have a certain amount of cultural and organisational features in common: 'A civilization constitutes thus a kind of moral milieu within which are immersed a certain number of nations, and of which each national culture is but a particular form' (Durkheim and Mauss 2006: 37). On this basis, regular economic, cultural and political exchanges are possible between the national cultures - or social entities - thus joined. Such exchanges may even be the prelude, by progressive 'composition' (Terrier 2017), to societal mergers. It is noteworthy that Durkheim and Mauss tried, as it were, to 'neutralise' the term 'civilisation': their proposal was to use it a classificatory concept to describe intersocial similarities beyond the boundaries of political societies.

To this end, they had to sever its association with substantial, normative conceptions of morality, and in particular detach it from the idea of 'orderly customs and mores': being part of a civilising process did not mean for colonial authorities, either French or British, to spread to the nonEuropean world some progressive ways of governing that they had tested themselves in Europe for the last half century - as if 'civilisation' was some reified thing that one nation possessed and could export abroad to those nations which did not yet possess it. In Durkheim and Mauss's conception, 
civilisation could no longer be 'exported'; it needed to be 'co-created'. It could only result from a slow process of progressive rapprochement, from the establishment of a shared 'total' space in which both metropolitan citizens and colonial subjects would come into contact and, as a result, would start exchanging a variety of elements, thereby signalling the beginning of a common civilisation capable of uniting them and in which their differences would be respected (at least some of them, probably not all): a shared language in addition to various dialects; tolerance for diverse religions put in contact in a secular space rather than a forced conversion of the nonChristian local subjects by missionaries (Meziane 2021); a reconfiguration of the economic spheres working to the advantage of all parties; and a changing of the ways of establishing families and inheriting property rights, which would be harmonised over time.

Besides, all Durkheimians and Maussians understood that the expansion of French 'civilisation' carried by the progress of French colonial armies into West Africa was not a guarantee for the establishment of democratic forms of government or for the incorporation of these regions into a broader global democratic 'world society', as contemporary sociologists would call it (Meyer et al. 1997). The progress of political societies towards a higher level of integration and into a reflexive community characterised as a community of nations was neither automatic nor linear. Mauss's students, like Jacques Soustelle, were very much aware that ethnicities and other political groups in the French overseas territories could belong to one expanding civilisation at one point in time, then retreat from it and then partake in another rising civilisation (Soustelle 1967). Civilisations were mortal just like nations or ethnicities. None of the Durkheimians believed that the creation of an international order, made of tens of newly independent nation states, would constitute the end point of history. First, a wide variety of political forms would continue to exist within the same period, the nation being only one of the many ways in which a polity could be organised, albeit in Mauss's view a particularly remarkable one. Second, this international order could well take up the form of a loose 'League of Nations', as after the Great War; however, as a league was a feeble way of associating independent polities together, it could lead to some more total forms of integration - for instance, as Mauss (2013) explicitly suggested, through the creation of one or several international federations.

In this process, sociology - and especially the kind of historical sociology that Mauss (2013) was pursuing in The Nation - could serve as a useful reminder for colonial policymakers and administrators, as well as for the international bureaucrats of the League of Nations, that the colonial project needed to tackle all dimensions and scales of development in a historical and global perspective. It should not confine itself to the political or 
constitutional dimension only, and it needed to move beyond both sheer 'colonial law-and-order' (or more bluntly, the old style of colonial domination, of which Mauss was highly critical) and local institution-building in the colonies. Due to the reframing of the concept of civilisation, described above, the expansion of French civilisation should not be envisaged as a step-by-step process whereby the populations of the colonies were made identical with those of the metropolis: a civilisation, as Mauss described it, is based on organisational and cultural adaptability (or harmony), not identity. Furthermore, in this conceptualisation, differences should ideally result from a process of bottom-up societal development in all areas fostered by intersocial exchange, as opposed to top-down imposition.

Some may be tempted to describe Mauss's position as a mere call to render colonisation more humane, while accepting its principle. There is no denying that we are here, once again, confronted with the fundamental ambiguity of Durkheimianism, which was already presented and discussed above. For the sake of clarity, however, it is worth distinguishing between two forms of acceptance of colonial rule by Durkheimians. First, Mauss could have 'accepted' colonisation in the sense of 'welcoming it' - for instance, as a way of bringing universally true principles of social organisation to non-European people: we have seen, however, that this was not his concept of civilisation. Second, Mauss could have 'accepted' colonisation in a more strategic sense: while sceptical towards the old principle of colonial expansion manifesting the exclusive will of a European sovereign, he could still have refrained from attacking it frontally on practical political grounds, preferring to put his effort into criticising its numerous excesses and abuses. He may, for instance, have considered vocal anti-colonialism from the metropolis a lost cause. ${ }^{6}$ We do not want to say that this second position is politically sound or morally correct; it is our belief, however, that we must conceptually distinguish it from the first.

In The Nation, there is undeniably acceptance of colonialism, as Mauss (2013) limits himself to denouncing the worst horrors of colonial armies and colonial administrators, as opposed to colonisation in toto. On the basis of that text alone, it is hard to determine the exact proportion of principle and strategy in this position. To shed some light on this issue, it is worth considering the numerous texts collected in Écrits politiques: during his entire career, and especially in the decade before the First World War, Mauss regularly published small essays and op-ed pieces in which he scathed Western political governments and corporations for their brutal violence and exploitative greed in the colonies (Mallard 2019). Admittedly, Écrits politiques does not entail indisputable evidence of Mauss's (1900: 645) opposition to the very principle of colonialism; nevertheless, some sentences come close to a general condemnation of all forms of imperialism, most clearly, in our view, the following one: 
When it comes to the relations between peoples, the ruling classes have imposed everywhere the rule of force and the principle of war. Peace and justice do not belong to the things that contemporary states are capable and willing to establish. . . . Fortunately, the Workers' International is organising, and it shall emancipate all workers, bring peace to all peoples, and realise human brotherhood. ${ }^{7}$

At any rate, Mauss's hopes were not centered on the ability of colonial subjects to push back colonial armies outside their territory and reclaim exclusive sovereignty - the very principle that Mauss combatted in his characterisation of the conduct of empires. Rather, his hopes lay in the creation of a transnational association of workers uniting subjects from all territories and all peoples.

For the time being, we may not be in a position to give a definitive answer to the question of Mauss's exact stance regarding colonialism, but we can see quite clearly that he did not envision a world in which decolonisation would happen in the near future - and we venture that such anticipation of long colonial rule may have prevented him from expressing a stronger criticism. Another conclusion we may draw from the study of his interwar activities is that his call to reflexivity did have some impact on the political representations of civil servants and administrators: through the diffusion of ethnographic methods in colonial administration and through dedicated teaching, Durkheimian sociologists and ethnologists could train colonial officers sent by the metropolis overseas. In other words, the historical role of Mauss's work went beyond that of a general epistemological dissent from the old Comtian philosophy of history espoused by the nineteenth century French colonial apologists (Todd 2021) - as a theory of progressive and linear steps from magical to rational, positive thinking. Mauss believed that ethnology and sociology could directly help colonial administrations 're-educate' their administrators along the lines of a pluralist conception of the colonial and/or international order (Mallard 2020). Since the colonial project was already ongoing, with ethnology a part of it, it could be re-routed towards the promotion of not just peace and rationality, along the lines developed by Durkheim, but also towards the promotion of a harmonious development of 'nations' administered under the French Empire through the recognition of a plurality of pathways towards autonomy and mutual respect. Ethnography had an essential role to play in this broad intellectual project. Through these endeavours, Durkheimian sociologists and ethnologists could influence colonial administrators in their role to socialise local populations into new judicial procedures and consultative modes of political representation, rather than delegate directly to these populations the power to self-govern themselves immediately (Koskenniemi 2001; Mazower 2010, 2012). 
Throughout the interwar period, Mauss sought to influence the colonial administrators he advised by grounding their colonial practice in a more humanistic understanding of the diversity of human experiences. But to spread that influence into the colonial territories was possible only if his students reached high positions in the colonial administration: Mauss thus discouraged his students from being too vocal about their scepticism towards France's colonial mission. In many ways, this tactic that Mauss implemented through his diverse endeavours - the Institute of Ethnology, the Musée de l'Homme, and the Chair of Sociology he obtained in 1931 at the Collège de France - worked, especially if one studies the careers of some his students in the colonial field (Mallard 2019). At this juncture, we may wonder, as we did with Durkheim himself, how and why so many scholars from the second generation of Durkheimian ethnologists in the interwar era were blinding themselves with regard to the colonial project; how and why they were incapable of seeing the discrepancy between their proposal for the future of colonialism, on the one hand, and the reality of its brutal, inhumane practices, on the other hand (Meziane 2021).

As Leo Coleman acknowledges in this issue, central figures in sociology and ethnology who were working outside metropolitan France but were familiar with the work of the Durkheimians - like Malinowski in Great Britain, arguably Mauss's closest counterpart across the Channel - also turned their attention in the 1920s to the question of how to establish international co-operation on sound anthropological principles. The attention they paid to the construction of the international order - including that developing between the metropolis and a colony, conceived as two possible nations in evolution or as one bigger nation in formation - ran much deeper into the analysis of the moral, cultural but also social types of exchanges, and clearly went beyond the approach favoured by legal scholars, who merely studied the legal sanctions that could preserve the international order against possible violations or threats from outside or within. Malinowski claimed, in a fashion that was similar to that of Mauss, that his analysis of the complex legal 'piling up' of rules and sanctions, which resulted from the colonial superposition of European laws on top of Indigenous codes and customs in the non-European world, could have direct relevance to the tasks and practices of colonial administrators meant to litigate conflicts within colonial contexts. Coleman demonstrates that Malinowski, rather than portraying colonial subjects as primary mimetic subjects driven by a supposedly unified 'archaic' collective representation, derived from the Durkheimian school in general, and Mauss's writings in particular, the notion that individuals, regardless of the level of social complexity reached by their society, could, by way of creative acts of interpretation, navigate complex systems of legal, religious and moral rules. 
In so doing, these anthropologists were in a position to challenge the racist conceptions of colonial subjects developed by certain colonial administrators in the British, French and German Empires, for whom Indigenous people only followed commands when they were backed up by the threat of force and constraint. ${ }^{8}$ At the same time, however, the 'colonial managerialism', as Coleman calls it, to which Mauss and Malinowski aspired, entailed the risk of tying themselves to the colonial administrators they hoped to influence, and missing the boat as forces conspired to bring to a close one hundred years of French and British imperial rule in Africa in the post-war era.

\section{The Post-War Redefinition of Post-Colonial Relations: Failed Attempts and Missed Opportunities}

\section{Managerial Internationalism and the Transformation of Ethnology into Expert Knowledge in the 1950s}

Alice Conklin demonstrates in this issue that although Mauss's students who formed the third generation of the Durkheimian school - expressed their criticism of many of the defining dimensions of colonial rule, like the widespread racist belief amongst colonial authorities in the existence of races and the superiority of their own over others, they missed the opportunity to critically engage with the question of how to end European colonialism in Africa and how to organise post-colonial relations between former metropolises and newly independent states. The conquest, occupation and systematic mass killings of minorities - Jews especially - by the National Socialist regime in Europe provided the context in which the question of racism and anti-racism was discussed by many of these Durkheimian scholars, like Claude Lévi-Strauss and Alfred Métraux, in the 1950s (Lentin 2005; Stoczkowski 2007).

The post-war positions of Durkheimian ethnologists were only marginally different from the international liberalism of the interwar experts in the fields of anthropology and ethnology who accepted colonial rule, as embodied by Malinowski or even Mauss: they did not situate themselves in a mental space in which decolonisation was a possibility. Their reflections did not extend - at least, in their writings - on the enormous practical issues that would arise in the context of secession, independence or state succession during the practical reality of decolonisation and the creation of new nation states out of the ashes of the former French, British, Dutch and Portuguese Empires. For them, the questions of state succession brought by the claims of anti-colonial movements in Vietnam, Algeria, India and much of the African world remained political issues that each empire would need to address according to its own rhythm, tradition and willingness; and 
these were issues for which neither ethnology nor sociology could provide an adequate answer, judging by their silence on this very question.

One has to emphasise that not every sociologist at the time shared their apparent avoidance of the topic of decolonisation. For instance, W. E. B. Du Bois, an eminent US sociologist of race and public intellectual engaged for years in the study of, and fight against, racially ordered domination, was very much involved in the attempt by anti-colonial intellectuals and US African Americans to 'give teeth' to the UN Declaration of Human Rights. They did so by lobbying the newly constituted UN Commission on Human Rights, established in 1946, to hear cases against UN member-states - in particular, for Du Bois, the US federal government as well as southern US states - and, should the UN Commission refuse to do so - as it did - to create a state in the US South where African Americans would be the majority, and to support the creation of the state of Liberia, where Africans enslaved and deported to the US through the Atlantic slave trade could resettle on the African continent (Anderson 2003).

While Du Bois's positions on the practical questions of how to put an end to both colonialism in Africa and the legacy of slavery in North America were very much publicised at the time of his writings, and strongly opposed, both by racist conservatives from the US South and by international liberals like Eleanor Roosevelt herself (Morris 2017), the position of Durkheimians - or their apparent lack of a position - on these questions seems to have made the selection of a Durkheimian sociologist, like Métraux, as Head of UNESCO's Race Bureau much easier for the Western governments who funded the Bureau. As Conklin demonstrates, the hiring of a white European ethnologist, with no experience studying race or ethnic relations outside the Latin American context, to head UNESCO's Race Bureau was emblematic of the timidity of the international liberals regarding the question of decolonisation. International liberals placed their hopes in a renewed form of depoliticised international expert management of the question of racism, which avoided the most controversial political issues, including how to handle the decolonisation process at the practical level - for example, who should be included in political consultations and how to organise the expected wave of constitution-writing processes in the newly independent states. What most Durkheimians were interested in, primarily, was the question of what kind of ethnological and anthropological knowledge would be useful to fight what they saw as the 'cultural' problem of racism, which, while being especially characteristic of colonial contexts, was universally present in any society. With this exclusive focus on the cultural dimension of the problem of colonialism, they failed to address the political issue of decolonisation on two counts: to begin with, they ignored the institutional question of regime change and state formation, and second, they neglected the ethical question of reparations - in other 
words, the question of what former colonial subjects could ask for from the former empires that had slaughtered, exploited and expropriated so many of their ancestors for generations.

From a long view, the global fight against racism which the Durkheimians were conducting from UNESCO's Race Bureau could be interpreted as a sign that they aligned with the global fight for decolonization. If we consider the context of the time, however, we must challenge this interpretation. The position of another Maussian sociologist, Jacques Soustelle, whose writings and administrative decisions in the post-war "colonial'" French administration were much more explicit about decolonisation than Métraux's ignorance of the issue, illustrates the ambiguities, discussed above, in the Durkheimians' position with respect to colonialism. Soustelle was both anti-racist and a proponent of the continuation, although in a renewed fashion, of French colonialism in Africa, particularly in Algeria. For instance, Soustelle and Mauss had co-founded the Comité anti-fasciste in the 1930s. After the war, Soustelle participated in the French constitutional reform of 1958, which granted Algerian Muslim citizens full French citizenship and the right to elect national representatives to the French Assembly in Paris for the first time in more than one hundred years of occupation. ${ }^{10}$ He advocated for the transformation of the French Republic into a multi-ethnic federation that would unite different populations across the Mediterranean in Europe and Africa into one big republic (Mallard 2019). He did not call his efforts to move the French Republic away from direct colonial rule in Algeria an attempt to 'decolonise' the French Republic, as such a word would have meant acknowledging that the Republic was in fact behaving like a classical colonial power; moreover, the use of that term would have been immediately associated with the lexicon of the pro-independence movements he was fighting against. Rather, Soustelle's position shows that when Mauss's former students expressed their support for an anti-racist programme, it did not necessarily translate into support for the cause of independence - as illustrated also by the position of Germaine Tillion (2005), another one of Mauss's students at the Institute of Ethnology, who argued that political independence and the immediate cessation of French investment would translate into economic dependence.

\section{Early Attempts at Decolonising the Durkheimian School of Ethnology}

Although the majority of Maussian ethnologists and sociologists did not explicitly address the political issue of decolonisation in the post-war era, as they focussed on the characteristically Durkheimian issue of how to fight racism and anti-Semitism after the Nazi atrocities, there were efforts to 'decolonise' ethnology and sociology in the 1960s and thereafter. For instance, young ethnographers and sociologists who worked in Algeria 
in the 1950s, like Pierre Bourdieu (1958), did not go as far as claiming to 'decolonise' Durkheimian ethnology, but they clearly distanced themselves from the classical Maussian perspective on the emergence of the international order as a result of exchange and societal combination and composition - a perspective, as we have seen above, which left the question of colonial rule unproblematised. In particular, Bourdieu articulated at great length a critique of Mauss-inspired Soustellian ethnography in which the 'total' relations - economic, cultural, political, legal, religious - between the French metropolis and French Algeria were portrayed as a series of gift exchanges (Mallard 2019).

While the generation of Soustelle and Tillion was increasingly associated with the defense of the French neo-colonial presence in North Africa, the schism between those earlier ethnologists and the new generation grew wider over time: according to Pierre Bourdieu and Abdelmayek Sayad (1964), his co-author, the first step for ethnographers was to get to know who the Algerians 'really' were, outside of the French influence, and what united them, rather than to assume that they could never coalesce as a 'nation', as Soustelle had previously argued. Whereas Tillion and Soustelle asserted that harmonious relations between European and non-European communities could still be steered by the French Republic in Algeria in the late 1950s, Bourdieu argued that French law in Algeria had always been deployed for the purpose of eliminating the presence of Algerian systems of rules, and hence existing customary law. Rather than being conceived as an experiment in global legal (or rather inter-societal) pluralism, French colonialism, according to Bourdieu, had been an experiment in legal domination.

As one of the authors of this article argued elsewhere (Mallard 2020), despite the demise of Soustelle's Mauss-inspired conception of the international (or rather, inter-societal), the crisis of ethnology caused by its association with colonialism, and the efforts of Bourdieu and others to 'decolonise' the ethnographic discourse produced in/on Algeria, the Durkheimian and Maussian influence did not disappear from ethnographic studies after Algerian independence. In 1975, the President of the French Republic Valéry Giscard d'Estaing asked Soustelle, by then the deputy of Lyon in the National Assembly, to write a report on the future of French research in anthropology and archaeology. As Soustelle (1975: 13) argued at the beginning of his report, possibly preaching to the choir, Mauss continued to determine the intellectual horizon under which French anthropologists constituted their scientific agenda. If ethnologists could no longer study the inter-societal exchanges that made the life of a civilisation, and how a plurality of 'nations' came into contact at the global level to create higher levels of integration, they could at least study those cultural practices that were observable within ethnic groups at the local level, either in the 'new context of cooperation with newly independent states', or in the metropolis, 
where 'French ethnographers should devote more resources to studying their own populations' in their ethnic diversity. ${ }^{11}$ The ethnographic focus on the international had, by then, disappeared from the French ethnological discourse that claimed Mauss as a founding father of the discipline. But it continued to be deeply associated with a (neo-)colonial mindset in which ethnography was meant to study the former colonial subjects, now treated as (potentially dangerous) foreign migrants within their former metropolis. The association between this kind of programme for ethnography, on the one hand, and the logics of the 'security nation state' and police projects related to the protection of law and order in contexts of cultural and legal plurality in the post-colonial European context, on the other, explains why Soustelle's practice of ethnography could be called 'neo-colonial' and why there are legitimate grounds to claim that some inspiration in Durkheimian ethnography should be decolonised today.

\section{What It Would Mean to 'Decolonise' the Durkheimian School of Sociology Today}

An important issue that we raise in this article is the polysemy associated with the term 'decolonisation' or claims to 'decolonise the canon'. Far from being simple terms with only one interpretation, they can mean very different things in different contexts. Understanding the history of such claims is therefore important. Some sociologists and ethnologists working in the Durkheimian tradition, like Soustelle or Tillion, opposed 'decolonisation' in the sense of new nations acceding to internationally recognised statehood and to internal manifestation of their political will through independent elections; still, they proposed ways to make the French Republic evolve from its colonial past by better integrating these populations. Others, like Bourdieu, have called for a complete decolonisation of France's relations with its second-class citizens in the colonies or quasi-colonial territories, like Algeria. Whatever they called their programme, whatever the role they gave to sociology or ethnology in the genesis of their political ideas, what matters here is to uncover the challenges that new ways of practising ethnology or sociology allowed them to overcome, the promises they failed to deliver and what direct or indirect consequences those failures had for the subjects they studied.

In many ways, French Durkheimian ethnology and sociology, whether pro- or anti-decolonisation, missed the opportunity to participate with newly independent states in 'decolonising' international relations in the 1960s and 1970s. Such attempts were much more clearly articulated by international law scholars from the Global South - conceived at the time as encompassing Latin America, Africa and Asia - who rebelled against the sanctity of contracts securing the economic rights acquired by Western 
private companies like oil concessions after independence (Schrijver 1997: 116). As one of the authors of this article has shown in Gift Exchange (Mallard 2019), French jurists of Algerian origin who took prominent positions in the newly independent Algerian state, like Mohammed Bedjaoui, were instrumental in trying to establish a 'new international economic order' (NIEO) based on principles of justice, sustainability and equality between states, one which was opposed by Western states (the United States and former European empires in particular). While 'modern' international lawyers advocated for the sovereign equality of states, the right to self-determination and the right to economic development thanks to international co-operation (Anghie 2005; Anghie et al. 2003), the push for the NIEO, which emerged from the Non-Aligned Movement and the Bandung Conference in the 1950s, went far beyond these points: the NIEO proposed a complete reform of how international law was practised and taught (Slobodian 2018). ${ }^{12}$ While these attempts to 'decolonise' certain disciplines, like international law, marked the academic field in the 1970s and beyond, they did not extend far into the world of social science.

A dialogue between the history of sociology, ethnology and international law is therefore necessary if one is to understand the present pathways that such disciplines could take to 'decolonise' some of their curricula, research practices and epistemologies. Although not all disciplines entertained the same link with either colonialism or decolonisation, they all could benefit from an exchange about their histories, as well as co-operation in making their future disciplinary standards more attuned to the need to revisit their past and their association with the colonial mindset.

\section{Notes}

1. Even Marcel Fournier's (1994) landmark biography of Marcel Mauss does not critically assess Mauss's contribution to the colonial project.

2. This was true at least until 1914 for Barrès, who acknowledged the key contribution of the colonial military forces in the victory of French Army against the Germans. In contrast, Maurras's criticisms of the French Republican version of colonialism remained intact after the Great War, as they were grounded on deeply racist and anti-miscegenatist views.

3. Durkheim used this phrase (in one occurrence only: Durkheim 1908: 46) to refer not to the colonies, but to Europe.

4. Christianity in general, and Protestantism in particular (with the canonisation of Grotius in international law) played an important role in paving the way for the establishment of international law as a discipline on a long history dating back to the Reform, rather than on the more controversial body of colonial rules that emerged from the European conquest of Africa, to which the Berlin Conference of 1885 had tried to give a sense of order. 
5. In the French context, this mode of governing was associated with constitutional liberalism, which rested on the very notion that sovereign power was bounded by the power of a constitution; in the British context, the rule of law and the balance of power were famously performed by the expansion of common law in the absence of a written constitution.

6. In a virulent article from 1902, for instance, Mauss complained of the lack of mobilisation of the European working class on the subject of the British colonial war in Transvaal (Mauss 1902).

7. 'En matière de rapports de peuple à peuple, les classes dirigeantes n'ont établi d'autre règne que celui de la force, d'autre principe que celui de la guerre. La paix, la justice ne sont pas choses que peuvent réaliser, que veulent réaliser les États actuels. Heureusement l'Internationale ouvrière s'organise, elle qui émancipera les travailleurs, qui pacifiera les peuples, qui réalisera la fraternité humaine'.

8. At the same time, the publication of Malinowski's diaries after his death revealed that he privately expressed a number of racist comments that left a stain on his work for many professional anthropologists, including his followers, like Raymond Firth (Clifford 1985).

9. The term 'colonial' was used by the Algerian pro-independence side, but the French administration designated the administration of Algeria and the office of the Governor General, which Soustelle occupied shortly after the War of Independence in 1954, as being part of the French metropolitan state, following the fiction that Algeria was a French department just like any other.

10. In contrast to Algerian citizens of European descent and local Jewish populations, Muslims did not benefit from the full rights of French citizenship from 1865 until 1958. Indeed, they were considered to be French 'nationals' but not full citizens, unless they made a formal request which included the renunciation of their right to access the legal arenas that litigated conflicts according to Muslim law. Such a demand would almost certainly have been interpreted by Muslims as a rejection of their religion (Islam), and not surprisingly the number of Muslim-Algerians who applied to obtain French citizenship during more than a century of French domination was very low (Manceron 2003).

11. In particular, Soustelle (1975) wrote, new generations of ethnologists should conduct ethnographies of 'populations of allogenic workers' from Algeria 'whose high density in metropolitan city centers represented a threat to integration', now conceived in the contemporary sense of 'assimilation'.

12. For instance, as Bedjaoui $(1968: 97,99)$ expressed, NIEO scholars understood it as the task of the international law scholars to 'create new law under the guise of progressive development', as well as their duty to analyse emerging 'norms known and accepted by most states to a greater extent than traditional law, in whose formulation most existing states [which had recently come into being through decolonisation wars] took no part'. Codifying obsolete rules would be completely useless, so instead of codification, NIEO legal scholars proposed to engage in an effort of harmonisation by basing their work 'on legal constructions embodying to the maximum extent possible the present trends of international law, the principles of the Charter, the right to self-determination, sovereign equality, ownership of natural resources, etc.'. 


\section{References}

Abi-Saab, G. 1991. 'Permanent Sovereignty over Natural Resources and Economic Activities’. In M. Bedjaoui (ed), International Law: Achievements and Prospects. Dordrecht: Martinus Nijhoff Publishers, 597-617.

Anderson, C. 2003. Eyes off the Prize: The United Nations and the African American Struggle for Human Rights 1944-55. Cambridge: Cambridge University Press.

Anghie, A. 2005. Imperialism, Sovereignty and the Making of International Law. Cambridge: Cambridge University Press.

Anghie, A., B. Chimni, K. Mickelson and O. Chinedu Okafor (eds). 2003. The Third World and International Order: Law, Politics and Globalization. Leiden: Brill.

Asad, T. (ed). 1973. Anthropology and the Colonial Encounter. Amherst, NY: Humanity Books.

Becker Lorca, A. 2015. Mestizo International Law: A Global Intellectual History 1842-1933. New York: Cambridge University Press.

Bedjaoui, M. 1968. First Report on Succession of States in respect of Rights and Duties Resulting from Sources other than Treaties. International Law Commission. http://legal.un.org/docs/?path = ../ilc/documentation/english/a_ cn4_204.pdf\&lang = EFS.

Boucheron, P., N. Delalande, F. Mazel, Y. Potin and P. Singaravélou. 2017. Histoire mondiale de la France [The Global History of France]. Paris: Éditions du Seuil.

Bourdieu, P. 1958. Sociologie de l'Algérie [The Sociology of Algeria]. Paris: Presses Universitaires de France.

Bourdieu, P. and A. Sayad. 1964. Le déraciment [The Uprooting]. Paris: Minuit.

Brubaker, R. 2015. 'The Return of Biology'. In Grounds for Difference. Cambridge, MA: Harvard University Press.

Chakrabarty, D. 2000. Provincializing Europe: Postcolonial Thought and Historical Difference. Princeton, NJ: Princeton University Press.

Clifford, James. 1985. 'On Ethnographic Self-Fashioning: Conrad and Malinowski’. In J. Clifford, T. C. Haller, M. Sosna and D. Wellbery (eds), Reconstructing Individualism: Autonomy, Individuality, and the Self in Western Thought. Stanford, CA: Stanford University Press, 140-162.

Cohen, W. 1971. Rulers of Empire: The French Colonial Service in Africa. Stanford, CA: Hoover Institute Press.

Cohn, B. S. 1996. Colonialism and Its Form of Knowledge: The British in India. Princeton, NJ: Princeton University Press.

Collins, R. 2012. 'Time-Bubbles of Nationalism: Dynamics of Solidarity Ritual in Lived Time'. Nations and Nationalism 18 (3): 383-397. doi:10.1111/ j.1469-8129.2011.00530.x.

Conklin, A. 2013. In the Museum of Man: Race, Anthropology and Empire in France, 1850-1950. Ithaca, NY: Cornell University Press.

Craven, M. 2007. The Decolonization of International Law: State Succession and the Law of Treaties. Oxford: Oxford University Press.

Dhermy-Mairal, M. 2018. 'L'unification du mouvement coopératif au Bureau international du travail: la "révolution silencieuse” d'Albert Thomas' [The 
Unification of the Cooperative Movement at the ILO: Albert Thomas' Silent Revolution]. Le Mouvement Social 2 (263): 15-29. doi:10.3917/lms.263.0015.

Durkheim, É. 1898. 'Représentations individuelles et représentations collectives' [Individual and Collective Representations]. Revue de métaphysique et de morale 6 (1898): 273-302. https://www.jstor.org/stable/40892316.

Durkheim, É. 1908. 'Pacifisme et patriotisme'. Bulletin de la Société française de philosophie 17: 31-70. http://classiques.uqac.ca/classiques/Durkheim_emile/ sc_soc_et_action/texte_3_13/patriotisme_pacifisme.html.

Durkheim, É. and M. Mauss. 1913. 'Note sur la notion de civilisation'. L'Année sociologique 12: 46-50. doi:10.1522/cla.mam.not1.

Durkheim, É. and M. Mauss. 2006. 'Note on the Concept of Civilisation'. In N. Schlanger (ed), Marcel Mauss: Techniques, Technology and Civilisation. Oxford: Berghahn Books, 35-41.

Foucault, M. 2003. Society Must Be Defended: Lectures at the College de France, 1975-76. Trans. David Macey. New York: Picador Editions.

Fournier, M. 1994. Marcel Mauss. Paris: Fayard.

Go, J. 2008. 'Global Fields and Imperial Forms: Field Theory and the US and British Empires'. Sociological Theory 26 (3): 201-229. doi:10.1111/ j.1467-9558.2008.00326.x.

Heilbron, J. 1995. The Rise of Social Theory. Minneapolis: University of Minnesota Press.

Koskenniemi, M. 2001. The Gentle Civilizer of Nations: The Rise and Fall of International Law 1870-1960. Cambridge: Cambridge University Press.

Lentin, A. 2005. 'Replacing "Race”, Historicizing “Culture” in Multiculturalism'. Patterns of Prejudice 39 (4), 379-396. doi:10.1080/00313220500347832.

L'estoile, B. de. 2007. Le goût des Autres: De l'Exposition coloniale aux Arts premiers [The Taste of Others: From the Colonial Exhibition to the First Arts]. Paris: Flammarion.

L'estoile, B. de, F. Neiburg and L. Sigaud (eds). 2005. Empires, Nations and Natives: Anthropology and State-Making. Durham, NC: Duke University Press.

Mallard, G. 2018. "The Gift as Colonial Ideology? Marcel Mauss and the Solidarist Colonial Policy in the Interwar Period.” Journal of International Political Theory 14 (2): 183-202. doi:10.1177/1755088217751515.

Mallard, G. 2019. Gift Exchange: The Transnational History of a Political Idea. New York: Cambridge University Press.

Mallard, G. 2020. 'The Eclipse of Global Legal Pluralism in Ethnology: A French Trajectory’. In P. S. Berman (ed), Oxford Handbook of Global Legal Pluralism. Oxford: Oxford University Press, 143-168.

Manceron, G. 2003. Marianne et les colonies: Une introduction à l'histoire coloniale de la France [Marianne and the Colonies: Introduction to French Colonial History]. Paris: La Découverte.

Marcel, J.-C. 2019. 'The Contribution of Célestin Bouglé to the Concept of International Society and His Work at the Centre de Documentation Sociale'. Paper presented at the Graduate Institute, Geneva, Graduate Institute of International and Development Studies.

Mauss, M. 1900. 'La guerre du Transvaal'. Le Mouvement socialiste, 1 June, 641-645. 
Mauss, M. 1902. 'À propos de la guerre du Transvaal'. Le Mouvement socialiste, 15 February, 289-296.

Mauss, M. 2013. La Nation [The nation]. Paris: Presses Universitaires de France.

Mazower, M. 2010. No Enchanted Palace: The End of Empire and the Ideological Origins of the United Nations. Princeton, NJ: Princeton University Press.

Mazower, M. 2012. Governing the World: The History of an Idea. New York: Penguin.

Mbembe, A. 2001. De la post-colonie: Essai sur l'imagination politique en Afrique contemporaine [On the Postcolony: Essay on Political Imagination in Contemporary Africa]. Paris: La Découverte.

Meyer, J. W., J. Boli, G. M. Thomas and F. O. Ramirez. 1997. 'World Society and the Nation-State'. American Journal of Sociology. 103 (1): 144-181. doi:10.1086/231174.

Meziane, M. A. 2021. Des empires sous la terre: Histoire écologique et raciale de la sécularisation [Empires Under the Ground: A Ecological and Racial History of Secularization]. Paris: La Découverte.

Morris, A. 2017. A Scholar Denied: W. E. B. Du Bois and the Birth of Modern Sociology. Berkeley: University of California Press.

Mucchielli, L. 1997. 'Sociologie versus anthropologie raciale: L'engagement décisif des Durkheimiens dans le contexte “fin de siècle” (1885-1914)’ [Sociology vs. Racial Anthropology: The Decisive Involvement of Durkheimians at the Turn of the Century]. Gradhiva 21: 77-95. https://www.persee.fr/doc/ gradh_0764-8928_1997_num_21_1_923.

Nisbet, R. 1974. The Sociology of Emile Durkheim. Oxford: Oxford University Press.

Pahuja, S. 2011. Decolonizing International Law: Development, Economic Growth and the Politics of Universality. Cambridge: Cambridge University Press.

Rajagopal, B. 2003. International Law from Below: Development, Social Movements and Third World Resistance. New York: Cambridge University Press.

Sarraut, A. 1931. Grandeurs et servitudes coloniales. Paris: Le Sagittaire.

Schmitt, C. (1950). 2003. The Nomos of the Earth in the International Law of the Jus Publicum Europaeum. New York: Telos Press.

Schrijver, N. 1997. Permanent Sovereignty over Natural Resources. Cambridge: Cambridge University Press.

Sibeud, E. 2004. 'Marcel Mauss: Projet de présentation d'un bureau d'ethnologie' [Marcel Mauss: Project of an Ethnology Bureau]. Revue d'histoire des sciences humaines 10 (1): 105-115. doi:10.3917/rhsh.010.0105.

Sibeud, E. 2009. 'Une libre pensée impériale? Le comité de protection et de défense des indigènes (1892-1914)’ [An Imperial Free Thought: The Committeee for the Protection of Indigeneous People]. 1900: Revue d'histoire intellectuelle 27 (1): 57-74. doi:10.3917/mnc.027.0057.

Singaravélou, Pierre. 2011. Professer l'Empire: Les 'Sciences Coloniales' en France sous la IIIe République. [Teaching Empire: The French Colonial Sciences under the Third Republic].Paris: Publications de la Sorbonne.

Slobodian, Quinn. 2018. Globalists: The End of Empire and the Birth of Neoliberalism. Cambridge, MA: Harvard University Press.

Soustelle, J. 1967. Les Quatre soleils [The Four Sunds]. Paris: Terre Humaine. 
Soustelle, J. 1975. Rapport sur la recherche française en anthropologie et en archéologie [Report on French Research in Anthropology and Archaelogy]. La Documentation française. Fonds Soustelle, 112AJ/68. Saint Denis: Archives Nationales.

Steinmetz, G. 2007. The Devil's Handwriting: Precoloniality and the German Colonial State in Qingdao, Samoa and Southwest Africa. Chicago: University of Chicago Press.

Steinmetz, G. 2008. 'The Colonial State as a Social Field: Ethnographic Capital and Native Policy in the German Overseas Empire before 1914'. American Sociological Review 73 (4): 589-612. doi:10.1177/000312240807300404.

Steinmetz, G. 2013. 'Major Contributions to Sociological Theory and Research on Empire 1830s-Present'. In G. Steinmetz (ed), Sociology and Empire: The Imperial Entanglements of a Discipline. Durham, NC: Duke University Press, $1-52$.

Stocking, G. W. 1987. Victorian Anthropology. New York: The Free Press.

Stoczkowski, W. 2007. 'Racisme, antiracisme et cosmologie lévi-straussienne: Un essai d'anthropologie réflexive' [Racism, Antiracism and Lévi-straussian Cosmology: An Essay of Reflexive Anthropology]. L'homme 182: 7-52. doi:10.4000/lhomme.29406.

Subrahmanyam, S. 2013. Aux origines de l'histoire globale: Leçon inaugurale prononcée le jeudi 28 novembre 2013 [The Origins of Global History]. Paris: Fayard, 2014.

Terrier, J. 2011. Visions of the Social: Society as a Political Project in France, 1750-1950. Leiden: Brill.

Terrier, J. 2012. “"Auch in unserer Zeit werden Götter in den Massen geboren”: Émile Durkheims Erklärungsansätze zur Entstehung gesellschaftlicher Ideale in der Moderne' [Even in Our Age Gods Are Born Among the Masses]. Berliner Journal für Soziologie 22 (4): 497-516. doi:10.1007/s11609-013-0202-y.

Terrier, J. 2017. 'Sur le caractère "composé” du social: Le concept de composition chez Durkheim et Mauss'. Conceptos historicos 3 (4): 110-135. https://dialnet .unirioja.es/servlet/articulo? codigo $=8035297$.

Terrier, J. and M. Fournier. 2013. 'Présentation: La Nation, une expédition dans le domaine du normatif'. In Marcel Mauss, La Nation. Paris: Presses Universitaires de France, 1-42.

Tillion, G. 2005. Les ennemis complémentaires : Guerre d'Algérie [Complementary Enemies: The Algerian War]. Paris: Tirésias.

Todd, 2021. A Velvet Empire: French Informal Imperialism in the Nineteenth Century. Princeton, NJ: Princeton University Press.

Tournès, L. 2011. Sciences de l'homme et politique: Les fondations philanthropiques américaines en France au XXe siècle [Human Sciences and Politics: Philanthropic Foundations in France in the Twentieth Century]. Paris: Éditions des Classiques Garnier.

Vec, M. and L. Nuzzo (eds). 2012. Constructing International Law: The Birth of a Discipline. Frankfurt: Klostermann. 